Article

\title{
Hydrometeorological Conditions for the Occurrence of Aeolian Processes on the Southern Baltic Coast in Poland
}

\author{
Marcin Hojan ${ }^{1, * \mathbb{D}}$, Jacek Tylkowski ${ }^{2}$ and Mirosław Rurek ${ }^{1}$ (D) \\ 1 Institute of Geography, Department of Landscape History Research, Kazimierz Wielki University in \\ Bydgoszcz, 85-033 Bydgoszcz, Poland; mirur@ukw.edu.pl \\ 2 Institute of Geoecology and Geoinformation, Faculty of Geographical and Geological Sciences, Adam \\ Mickiewicz University, Krygowski 10, 61-680 Poznań, Poland; jatyl@amu.edu.pl \\ * Correspondence: homar@ukw.edu.pl
}

Received: 15 September 2018; Accepted: 26 November 2018; Published: 27 November 2018

\begin{abstract}
This article presents the temporal and spatial variability of hydrometeorological conditions conducive aeolian processes on the Southern Baltic coastal zone in Poland. The analysis made use of daily meteorological (wind, temperature, and rainfall) and hydrological (sea level) data from 1961 to 2010. Data for four stations (Świnoujście, Kołobrzeg, Ustka, Hel) were provided by the Institute of Meteorology and Water Management in Warsaw. A time decomposition of hydrometeorological conditions conducive to the initiation and intensification of aeolian processes in the coastal zone was also performed. In addition to their scientific significance, the temporal and spatial conditions for aeolian processes on the Baltic coast of Poland have an essential utilitarian significance. Modern aeolian processes on the Baltic coast limit the development potential of the coastal zone. Aeolian processes have a positive and negative impact on geomorphological transformation of the sea coast. They take part in the reconstruction of the beach and foredunes after storms. In periods between storms, coastal wind is seen to decrease the balance of beach sediments and lowers the beach area. On the other hand, onshore wind favors, among other things, filling of tourist infrastructure and development located at the hinterland of the beach and dunes. Hydrometeorological conditions especially favorable to the intensification of aeolian processes are the main determinants of geomorphological changes in the coastal zone (some of which can be extreme). Temporal and spatial analysis of hydrometeorological conditions conducive to aeolian processes is important for many areas of human activity, especially those concerning protection, management, and development of the coast.
\end{abstract}

Keywords: aeolian processes; hydrometeorological conditions; onshore and offshore winds; Southern Baltic coast

\section{Introduction}

To determine how geo-ecosystems of the coastal zone function, it is necessary to identify in detail the hydrometeorological conditions that most influence the trend, cyclicality, and seasonality of geomorphological processes. An example of such a process is aeolian transport. It constitutes an important factor for shaping beaches, coastal dunes and sandy cliff slopes. Research on aeolian processes was carried out irregularly and in various parts of the Polish Baltic coast, including: Świna Gate Sandbar [1], Wolin island [2,3], Kołobrzeg [4], Mierzeja Łebska [4-11], Lubiatowo [12], and Hel [13]. The dynamics of aeolian transport depend on hydrometeorological factors and the type of substrate surface, especially its roughness and moisture $[4,9,10,14,15]$. Meteorological conditions (including the direction and speed of wind, atmospheric precipitation, and air and ground 
temperature) determine the initiation, intensity, and duration of aeolian processes. Sea level, on the other hand, determines the availability of beach sediments, which may be subject to deflation, transport, and aeolian accumulation.

Since the internal climate of the Earth varies constantly, climate models are devoted to analyze the non-linear interactions and different time responses of the components in the climate system. With regard to the atmosphere, changes in temperature, rainfall, wind speed and direction are mainly subject to particular analysis [16-18]. Atmospheric parameters may vary over the year. Changes in wind direction affect regional changes in atmospheric factors, such as rainfall and cloudiness [19]. What is more, changes in wind direction and other meteorological factors affect the morphological changes of the coast [20]. Statistical modeling is also used; it takes into account temperature and atmospheric precipitation in the Baltic Sea basin [21]. Research has shown that there are changes in wind directions and speeds in the Estonia region [22]. Sandy beaches, separated from the land by foredunes, favor transport of sand along the coast. Prolonged, above-average winds have a greater impact on sand transport than relatively short-lived strong winds during storms [23]. The analysis of available meteorological data allows to observe changes on the coast occurring as a result of intensifying aeolian processes.

The following take part in development of the beach: Coastal currents in the littoral zone, waves in the inflow zone causing beach erosion during the development of storms and accumulation of sand on the beach during the weakening of storms and aeolian processes in interstorm periods [9]. Material provided by marine alongshore currents comes from eroded cliffs [4,24].

Wind speed, air temperature, as well as air and substrate humidity affect the fraction of exhausted mineral material [10]. Granulation of dunes and sands of the Southern Baltic coast is mainly made up of sands. Research on sediments of sandy beaches in the Baltic Sea coastal zone in Lithuania [25] and in Poland [12] has shown that beaches in these countries are made of fine-grained sands. Other studies on beach sediments on the Curonian Spit, Vistula and Hel have shown that the beaches are dominated by medium- and coarse-grained sand, whereas foredunes are built of fine-grained sands $[13,26]$. This is in line with the results of a study by Reference [12], which indicated that the graining of beach sediments in Świnoujście, Kołobrzeg, Ustka and Hel is dominated by medium- and fine-grained sands. Coarse sands are found on beaches along which currents and sea waves blur clay thresholds [12].

So far, research carried out in the Baltic Sea basin has been related to various hydrometeorological factors. The rise of sea level $[27,28]$, storm frequencies [29-32] and climatic conditions (also those in other parts of the world) [33] may affect the functioning of aeolian processes in the geosystem of the South Baltic coasts. This work aims to analyze meteorological data, which will allow to establish to answer to the following question: Do hydrometeorological conditions changing in time and space translate into variability of conditions for potential initiation and intensity of aeolian processes in the Polish coastal zone of the Southern Baltic? For this purpose, hydrometeorological threshold values for the potential favorable conditions of aeolian processes were defined, time dynamics and spatial variability of hydrometeorological conditions were indicated, and frequency of intensification of aeolian processes in relation to particularly conducive hydrometeorological conditions was presented. In the Polish coastal zone of the Baltic Sea, this type of research has not yet been done.

\section{Materials and Methods}

\subsection{Aim and Methods}

The main aim of this work was to conduct a temporal and spatial analysis of hydrometeorological conditions potentially favorable (initiating) and particularly conducive (intensifying) to aeolian processes in the Southern Baltic's Polish coastal zone. The occurrence of these conditions was accompanied by fulfillment of all threshold values. The conditions were classified into two groups (threshold values): 
- Potentially favorable to initiation of aeolian processes (maximum wind speed $\geq 4 \mathrm{~m} \cdot \mathrm{s}^{-1}$, no precipitation in the last two days, average daily air temperature $>0{ }^{\circ} \mathrm{C}$, maximum sea level (storm level) $<570 \mathrm{~cm}$ ).

- Particularly conducive to intensification of aeolian processes (maximum wind speed $\geq 10 \mathrm{~m} \cdot \mathrm{s}^{-1}$, precipitation $<5 \mathrm{~mm} / 2$ days, minimum air temperature $>0{ }^{\circ} \mathrm{C}$, maximum sea level (average level over many years) $<\sim 502 \mathrm{~cm}$ ).

The above meteorological threshold values were derived from direct field studies of aeolian transport dynamics on the Polish Baltic coast. To determine the impact of weather conditions on the occurrence of aeolian processes in the South Baltic coastal zone, field research was conducted in both the dune coastal zone $[1,3,4,17,18,34,35]$ and the cliff coastal zone $[2,36,37]$. It is assumed that the mobilization of sandy sediments on the beach begins at wind speeds of $4-5 \mathrm{~m} \cdot \mathrm{s}^{-1}$. This threshold estimated to be $4.4 \mathrm{~m} \cdot \mathrm{s}^{-1}$ for the finest dry sands, and $10 \mathrm{~m} \cdot \mathrm{s}^{-1}$ for moist material [38]. Marked intensification of aeolian transport occurs during winds blowing from the sea, as well as parallel to the coast, as they buffet the entire beach zone and the slopes of dunes and cliffs. Aeolian processes are limited by atmospheric precipitation, which increases the moisture of surface sediments and limits their ability to move. Field studies [2] and regression analysis (atmospheric precipitation-aeolian transport) revealed that aeolian transport occurs when the sum of atmospheric precipitation from the last two days is $<5 \mathrm{~mm}$. In the case of pluviometric conditions, the mobilization of sand as a result of splashing was not accounted for. Apart from wind speed higher than $8 \mathrm{~m} \cdot \mathrm{s}^{-1}$, movement of sand grains due to splashing is responsible for many factors related to, among others, kinetic energy of rain, morphology and forms of land cover during rainfall [10]. Many factors are responsible for the movement of sand as a result of splashing during rainfall. These include the kinetic energy of the rain, and the morphology and types of surface cover. Splashing of sand on the beach takes place even in situations when wind shear speeds are too low to initiate aeolian transport [39]. Aeolian transport is also determined by thermal conditions $[7,10]$. When surface-level sediments are frozen, the movement of sand is impossible. The initiation of aeolian transport therefore begins when the average daily air temperature is $>0{ }^{\circ} \mathrm{C}$. Yet, there are no limitations on the movement of sand when the temperature is above freezing. The dynamics of aeolian processes are also related to the availability of beach sediments. During storm surges ( $\geq 570 \mathrm{~cm}$ in the Polish Baltic coastal zone), the sea level is high, making the availability of beach sediments for aeolian processes low (beach sediment may be available in the upper beach area), and sometimes cancelling it altogether (e.g., a narrow beach in the cliff coastal zone). For this reason, it was assumed that the conditions for initiation of aeolian processes occurred on days when sea level was below $570 \mathrm{~cm}$. Particularly conducive to intensification of aeolian processes were wide beaches and a maximum sea level lower than the average sea level over the analyzed period, i.e., $\sim 502 \mathrm{~cm}$. This temporal and spatial analysis of how sea conditions affect aeolian processes was based on daily sea level data from mareographic stations in Świnoujście, Kołobrzeg, Ustka, and Hel. Only the Baltic High System (BHS) (based on the Kronstadt sea-gauge) was used. The estimated difference between the Normal-Null (NN)- and BHS-based systems is about $15 \mathrm{~cm}$ (the Kronstadt system is higher). Although Poland uses a high system based on the Kronstadt sea gauge, the registration and recording of sea levels is based on the Normal-Null reference system [29].

\subsection{Hydrometeorological Data}

This study is based on daily hydrometeorological data from 1961 to 2010 concerning: Average, maximum, and minimum air temperature; average and maximum wind speed; the sum of atmospheric precipitation; and average, maximum, and minimum sea level. The data was provided by the Institute of Meteorology and Water Management in Warsaw (https://danepubliczne.imgw.pl). Data was collected from four coastal stations in Świnoujście, Kołobrzeg, Ustka, and Hel (Figure 1). One drawback of these stations is that they are located behind the coastal dunes, which means that recorded wind speeds may be lower than those actually occurring on the beach. 


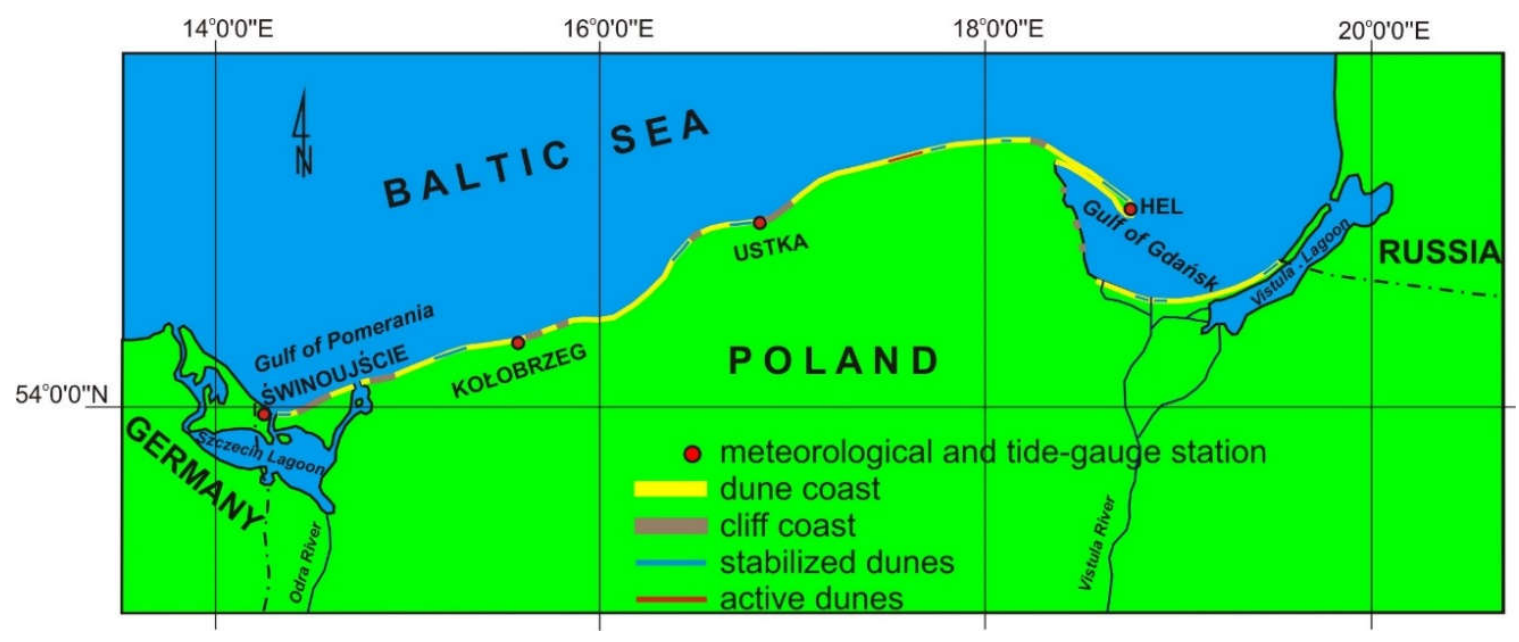

Figure 1. Area of research-location of measurement stations in the Polish Baltic coastal zone.

Wind directions were not taken into account in the study. It was assumed that aeolian processes operating on the beach occur with all directions of wind: Onshore, offshore, alongshore.

\subsection{Study Area}

The Polish coast has a length of $500 \mathrm{~km}$ [40]. It represents two basic types of coastline: Dune and cliff (Figure 1) [41]. Out of this, $80 \%$ is constituted by dune, developing in the Holocene. These are usually sandy barriers with a height of 2 to $35 \mathrm{~m}$. When it comes to dune shores, about $15 \%$ are constituted by accumulative stretches and around 35\% by erosional stretches [1]. Cliffs occupy about $15 \%$ of the sea shore [40]. They were created during the Holocene and contemporary erosion of frontal moraines. Moraines are built of glacial clays, usually $10-95 \mathrm{~m}$ high, as well as fluvioglacial sand and clays accumulated in the form of ground moraines, most often 6-15 $\mathrm{m}$ high. A small part (a few \%) in estuarine sections of rivers is constituted by a low coast of flood plains or organic accumulation. The height of this type of coastline is $0-5 \mathrm{~m}$ above sea level. Aeolian processes occur on all coastal types, especially in the beach zone. Aeolian processes are also observed on the slopes of dunes and cliffs.

Four areas were selected for the analysis: Świnoujście, Kołobrzeg, Ustka, Hel. Distances between these areas are around $90-130 \mathrm{~km}$. The Świnoujście area covers the section located east of Świnoujście. It is a dune section of the coast, which currently comprises an accumulative section. The Kołobrzeg zone west of the Parseta River is a dune section. On the other hand, there is a clay shore east of the Parseta River, with a height of 2-6 m above sea level. The western part of the Ustka area is a dune section. There are sand and clay cliffs up to $41 \mathrm{~m}$ above sea level in the eastern part of this area near Debina. The Hel area, on the other hand, constitutes a spit section of the coast, which is $36 \mathrm{~km}$ long. There are also inland dunes in the final part of the Hel Peninsula.

\section{Results}

\subsection{Hydrometeorological Conditions}

Analysis of meteorological data revealed that from 1961 to 2010, the maximum daily wind speed was lower than $10 \mathrm{~m} \cdot \mathrm{s}^{-1}$ only in Kołobrzeg in 1989, 1991, 2005, 2009, and 2010. In these years, the proper anemometric conditions for aeolian processes in beach sediments wet from precipitation did not occur. The highest maximum wind speed occurred on the eastern coast (Ustka $26 \mathrm{~m} \cdot \mathrm{s}^{-1}$ in 2004, Hel $23 \mathrm{~m} \cdot \mathrm{s}^{-1}$ in 1999). The average annual wind speed was highest in Hel $4.4 \mathrm{~m} \cdot \mathrm{s}^{-1}$ and Ustka $4.3 \mathrm{~m} \cdot \mathrm{s}^{-1}$ (exceeded the threshold value of $4 \mathrm{~m} \cdot \mathrm{s}^{-1}$ for initiation of aeolian processes in dry sandy sediments), and significantly lower in Świnoujście $3.7 \mathrm{~m} \cdot \mathrm{s}^{-1}$ and Kołobrzeg $3.2 \mathrm{~m} \cdot \mathrm{s}^{-1}$. The anemometric conditions in the eastern zone of the Polish Baltic coast were more favorable to aeolian processes (Figure 2). 


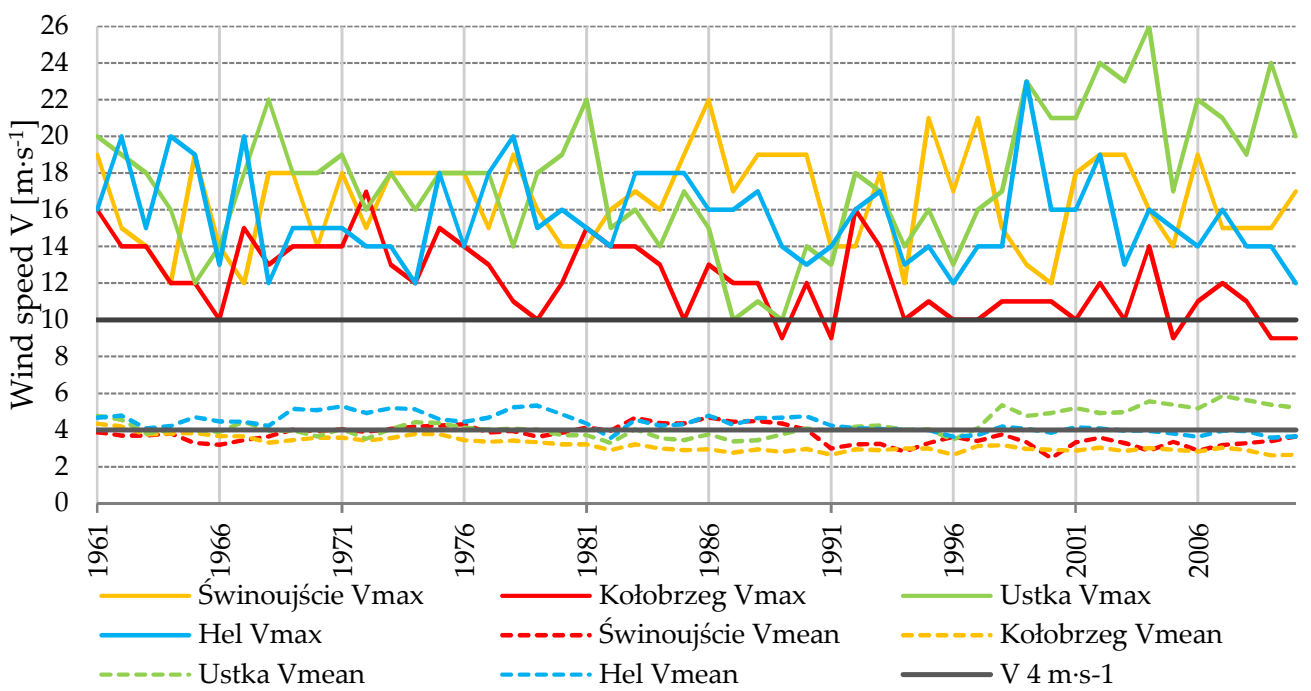

Figure 2. Annual dynamics of wind speed in the Polish Baltic coastal zone.

Pluviometric conditions in the open coastal zone of the Baltic (Ustka and Kołobrzeg) were less favorable to aeolian processes than those in bay areas (Świnoujście and Hel). In Ustka and Kołobrzeg, the following were confirmed to be significantly higher: Average annual sum of precipitation $(702.2 \mathrm{~mm}$ and $636.6 \mathrm{~mm}$ ); average annual number of days with precipitation (181 and 180 days); and maximum daily sum of precipitation (94.2 and $85.2 \mathrm{~mm}$ ). In Świnoujście and Hel (near the Pomeranian and Gdańsk Bay), the following were confirmed to be significantly lower: Average annual sum of precipitation (561.5 and $586.1 \mathrm{~mm}$ ); average annual number of days with precipitation (169 and 177 days); and maximum daily sum of precipitation $(58.7$ and $77.1 \mathrm{~mm})$. Pluviometric conditions in the central zone of the Baltic coast (Kołobrzeg and Ustka) were thus less favorable to aeolian processes than those in the western (Świnoujście) and eastern (Hel) zones (Figure 3).

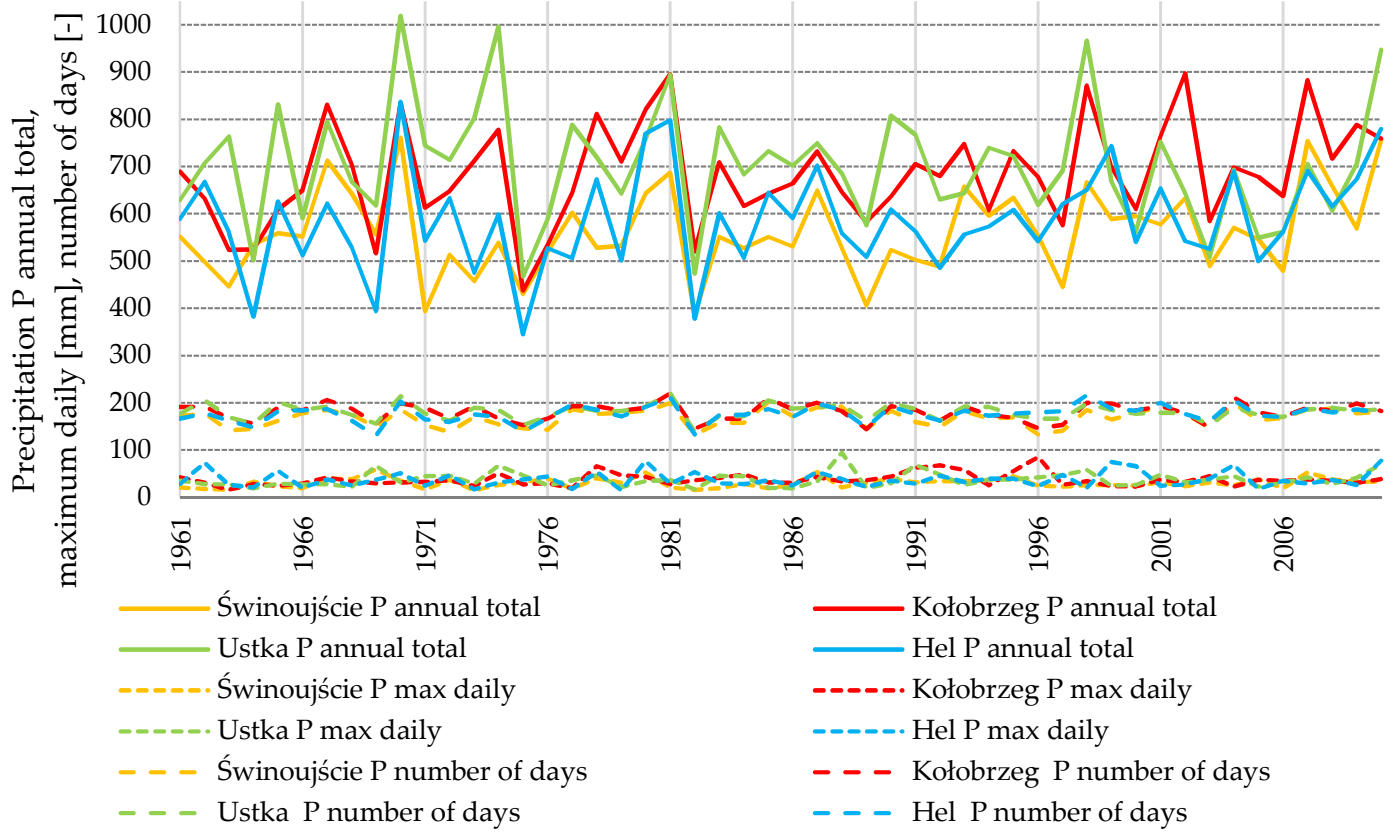

Figure 3. Annual dynamics of precipitation in the Polish Baltic coastal zone.

Each year, the average annual air temperature was similar across the entire Baltic coast zone. This confirms the rule that thermal conditions are more spatially homogenous than pluviometric and anemometric conditions. The average annual air temperature for the analyzed period decreased from 
$8.5^{\circ} \mathrm{C}$ in Świnoujście, to $8.2^{\circ} \mathrm{C}$ in Kołobrzeg, to $8.1^{\circ} \mathrm{C}$ in Ustka and Hel. The occurrence of aeolian processes is limited by the freezing of surface settlements $\left(t_{\max } \leq 0{ }^{\circ} \mathrm{C}\right)$. The most days with freezing temperatures were recorded in the eastern coastal zone in Hel, with an annual average of 28 days. Slightly fewer days with freezing temperatures were recorded in the remaining coastal zone, with an annual average of 23 to 25 days. The conditions for aeolian processes were particularly unfavorable in 1963, 1969, 1997, and 2010, when there were over 50 days with freezing temperatures recorded on the entire coast (Figure 4 ).

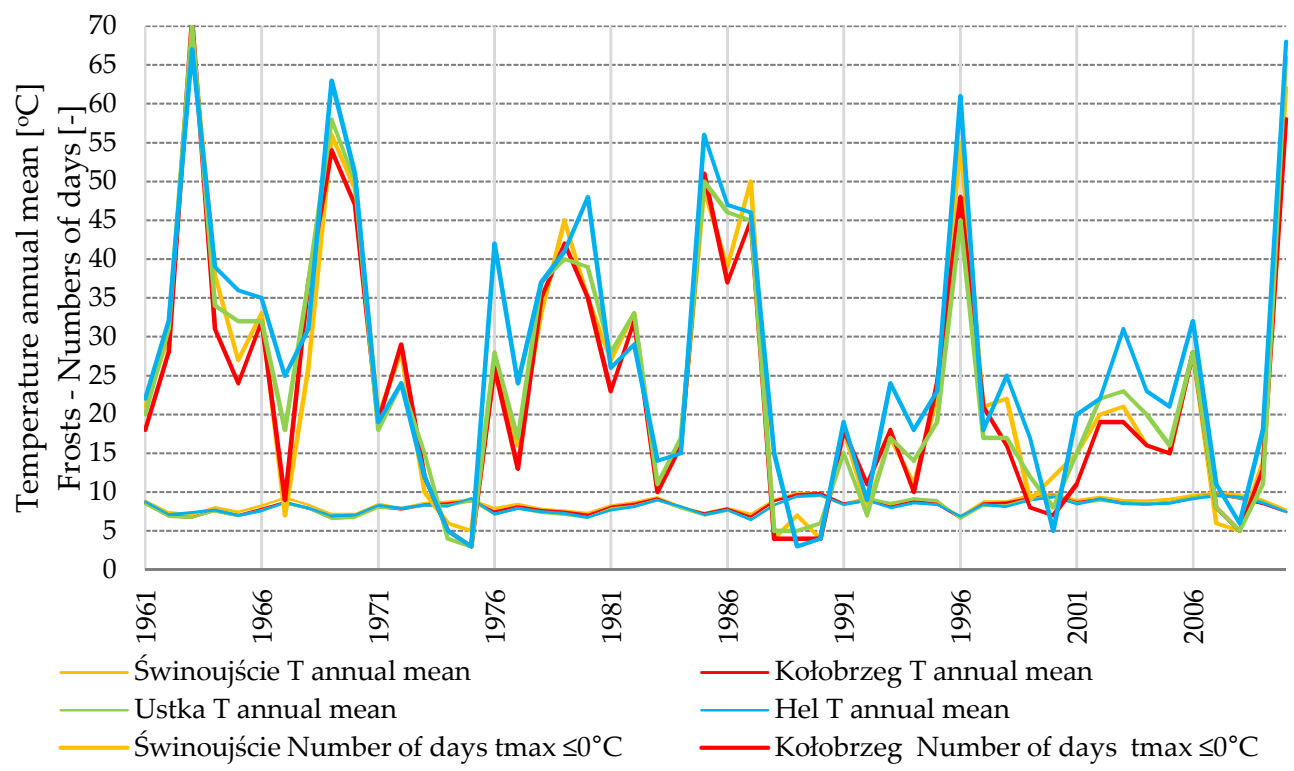

Figure 4. Annual dynamics of air temperature in the Polish Baltic coastal zone.

The annual dynamics of the maximum, average, and minimum sea level from 1961 to 2010 are very temporally and spatially varied (Figure 5). The average sea level ranged from $500 \mathrm{~cm}$ in Świnoujście to $504 \mathrm{~cm}$ in Hel. The absolute maximum sea level was $661 \mathrm{~cm}$ (Świnoujście—4 November 1995), and the absolute minimum sea level was $375 \mathrm{~cm}$ (Świnoujście—4 November 1979). The amplitude of sea-level fluctuations in the Polish Baltic coastal zone was, thus, $286 \mathrm{~cm}$. It was only in 1966 that no excess of storm level $\mathrm{H}_{\max }>570 \mathrm{~cm}$ was recorded at any of the stations. There were no limitations on the availability of beach sediments for aeolian processes on any day of that year.

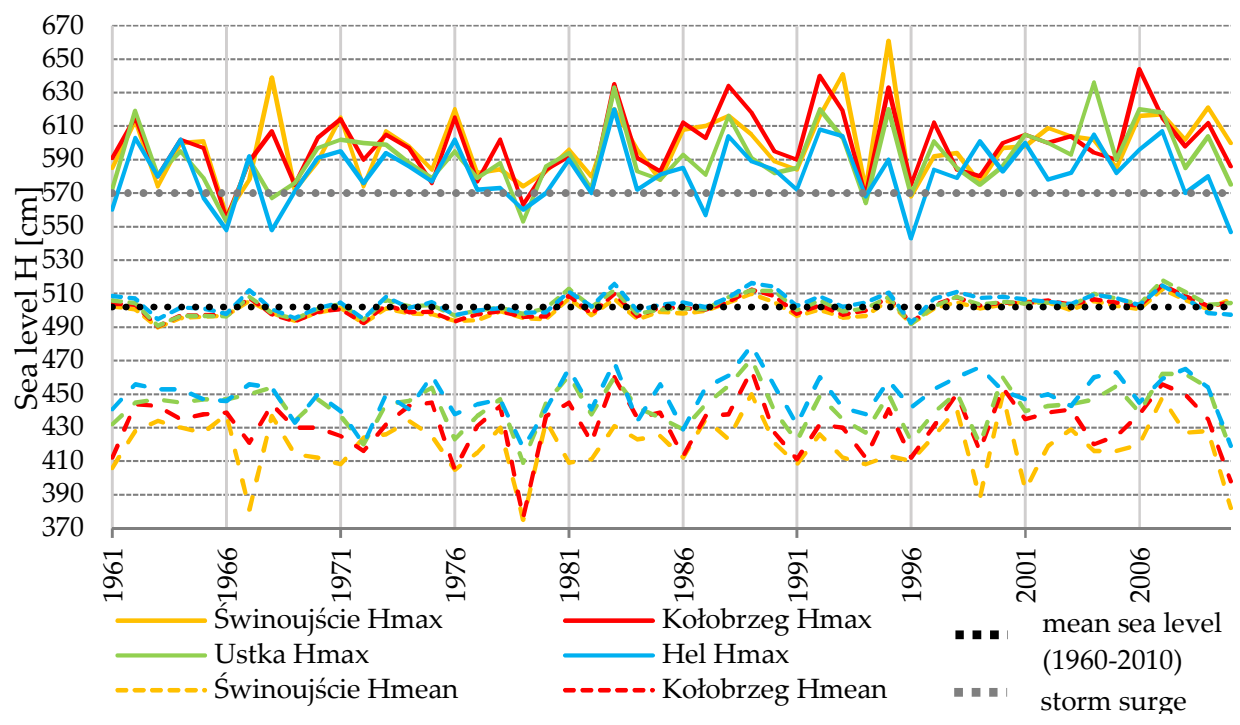

Figure 5. Annual dynamics of sea level in the Polish Baltic coastal zone. 
Particularly favorable conditions for intensification of aeolian processes occurred in the entire coastal zone when the maximum sea level was lower than the average sea level from the analyzed period $(\sim 502 \mathrm{~cm})$, and especially when the sea level was exceptionally low $\left(\mathrm{H}_{\min }<430 \mathrm{~cm}\right)$. It was then that surface-level beach sediments were most available for aeolian processes. Such events $\left(\mathrm{H}_{\min }<430 \mathrm{~cm}\right)$ occurred in the entire coastal zone in 1972, 1979, and 2010. The greatest differences in sea level were recorded on the west coast (Świnoujście and Kołobrzeg), where storm surges and post-storm level drops were particularly significant. Relatively small differences in maximum and minimum sea level occurred on the east coast in Hel.

\subsection{Potentially and Particularly Favorable Hydrometeorological Conditions for the Occurrence of Aeolian Processes}

Temporal and spatial analysis of hydrometeorological conditions for initiation of aeolian processes revealed a greater annual average of events on the coast of the Pomeranian Bay (Świnoujście, 92 days) and the Gdańsk Bay (Hel, 96 days) than in the open coastal zone (Kołobrzeg, 64 days; Ustka, 87 days) (Table 1). Along the entire coast, the greatest number of days potentially beneficial for initiation of aeolian processes was found in the decade of 1971-1980 (annual average of 93 days) and the least days in the decade of 2001-2010 (annual average of 79 days). This happened on the most days in 1975 (average of 125 days) and the least days in 2004 (average 65 days). For the occurrence of hydrometeorological conditions potentially favorable to initiation of aeolian processes, all thermal, precipitation, wind, and sea criteria must be fulfilled simultaneously.

Table 1. Average number of days per year with conditions potentially favorable to initiation of aeolian processes in the Polish Baltic coastal zone.

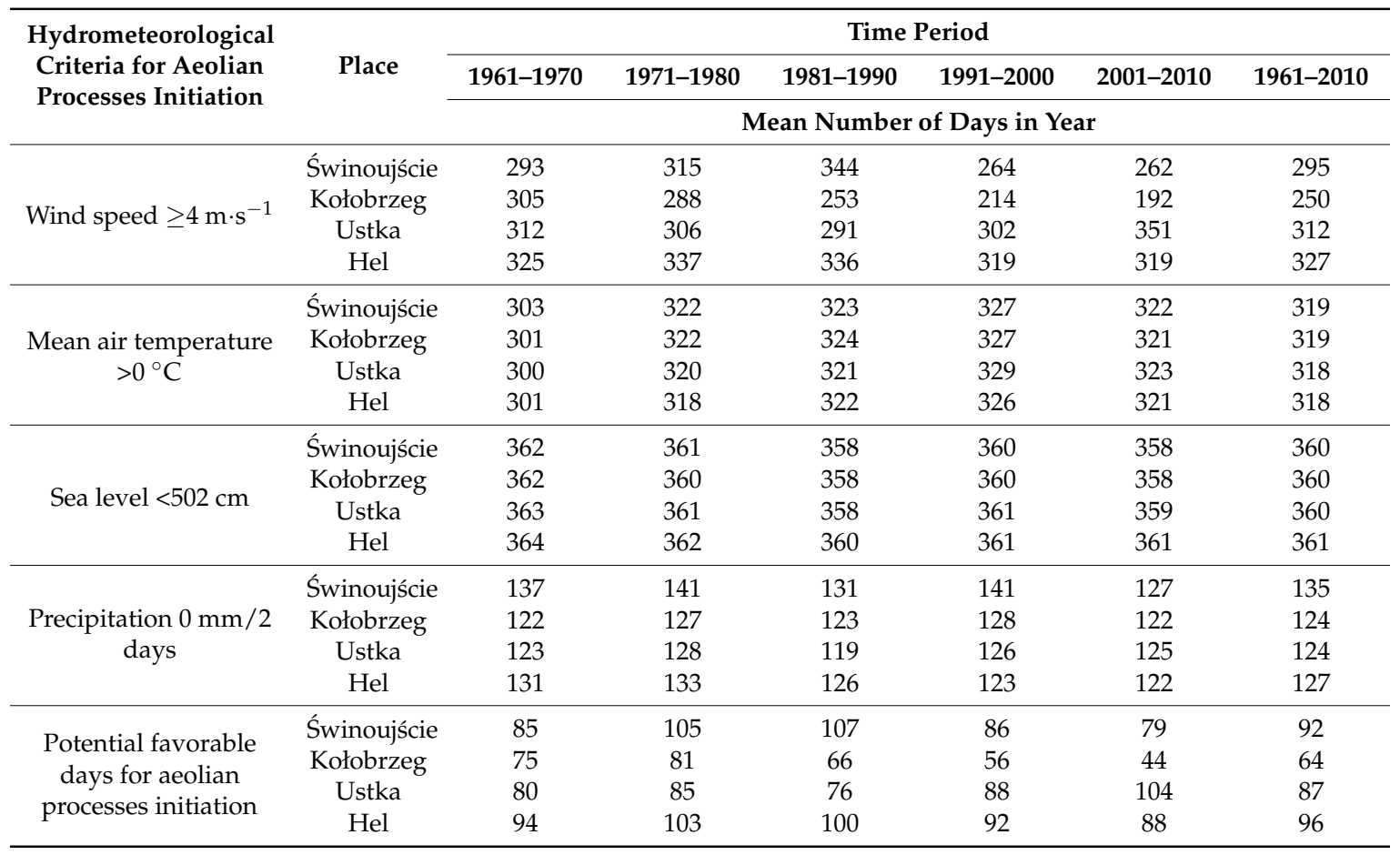

This is why the occurrence of all these conditions at once in the entire Baltic coastal zone is significantly rarer (annual average of 85 days) than their occurrence individually (sea level, average 360 days; air temperature, average 319 days; wind speed, average 296 days; and precipitation, average 128 days). During the analyzed period, there was a statistically significant $(p<0.05)$ increase in the number of days per year with an average air temperature of $>0{ }^{\circ} \mathrm{C}(\mathrm{r} \sim+0.3)$, and a decrease in the number of days per year with a maximum wind speed of $\geq 4 \mathrm{~m} \cdot \mathrm{s}^{-1}(\mathrm{r} \sim-0.5)$. Only in Ustka was there 
an increase in the number of days per year with a wind speed of $\geq 4 \mathrm{~m} \cdot \mathrm{s}^{-1}(\mathrm{r} \sim+0.9)$. The remaining hydrometeorological conditions, i.e., precipitation of $0 \mathrm{~mm} / 2$ days and sea level $<570 \mathrm{~cm}$, exhibited a statistically insignificant $(p>0.05)$ downward trend in the number of days per year, with a low correlation $(\mathrm{r}<-0.3)$.

Analysis of the number of days per year with favorable conditions for initiation of aeolian processes revealed a statistically insignificant downward trend for Świnoujście and Hel (r -0.2), and a statistically significant downward trend for Kołobrzeg $(\mathrm{r} \sim-0.7)$. Only for the central coast in the region of Ustka was a statistically significant upward trend recorded $(r \sim+0.4)$ (Figure 6 ).

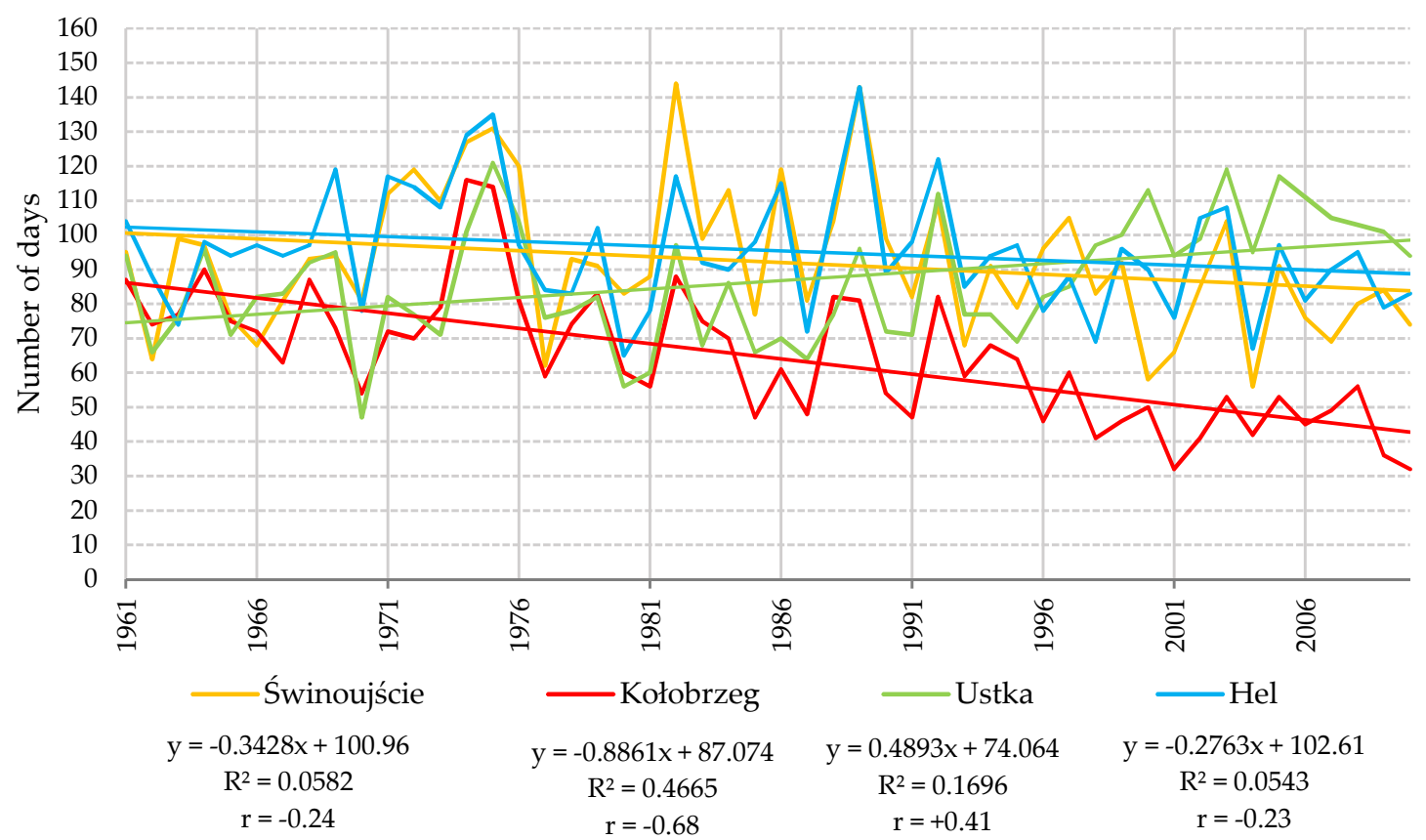

Figure 6. Annual trend of days with potentially favorable conditions for initiation of aeolian processes in the Polish Baltic coastal zone.

Temporal and spatial analysis of hydrometeorological conditions particularly conducive to intensification of aeolian processes revealed a greater average annual number of events in Świnoujście and Hel (4 days) than in Ustka (3 days) and Kołobrzeg (1 day) (Table 2). Conditions particularly conducive to intensification of aeolian processes occurred on the most days in the decade of 1971-1980 (annual average of 5 days), and on the least days in the decade of 1991-2000 (annual average of only 1 day). This happened on the most days in 1976 (average of 9 days) and the least in 1990, 1991, and 1997 (no days). Intensification of aeolian processes in the coastal zone may only occur when all hydrometeorological criteria are fulfilled simultaneously. Such events in the entire Baltic coastal zone are thus very rare (annual average of 3 days). The individual hydrometeorological conditions of these events occur more frequently (air temperature-average of 290 days, precipitation-average of 281 days, sea level—average of 140 days, and wind speed—average of just 10 days). During the analyzed period, there was a statistically significant $(p<0.05)$ increase in the number of days per year with a minimum daily air temperature of $>0{ }^{\circ} \mathrm{C}(\mathrm{r} \sim+0.3)$, and a decrease in the number of days per year with a maximum wind speed of $\geq 10 \mathrm{~m} \cdot \mathrm{s}^{-1}(\mathrm{r} \sim-0.6)$. Only in Ustka was there an increase in the number of days per year with a wind speed of $\geq 10 \mathrm{~m} \mathrm{~s}^{-1}(\mathrm{r} \sim+0.5)$. The remaining hydrometeorological conditions, i.e., precipitation of $<5 \mathrm{~mm} / 2$ days and sea level $<502 \mathrm{~cm}$, exhibited a statistically insignificant $(p>0.05)$ downward trend in the number of days per year, with a low correlation $(\mathrm{r}<-0.3)$. 
Table 2. Average number of days per year with conditions particularly conducive to intensification of aeolian processes in the Polish Baltic coastal zone.

\begin{tabular}{|c|c|c|c|c|c|c|c|}
\hline \multirow{3}{*}{$\begin{array}{c}\text { Hydrometeorological } \\
\text { Criteria for Aeolian } \\
\text { Processes } \\
\text { Intensification }\end{array}$} & \multirow{3}{*}{ Place } & \multicolumn{6}{|c|}{ Time Period } \\
\hline & & 1961-1970 & 1971-1980 & 1981-1990 & 1991-2000 & $2001-2010$ & 1961-2010 \\
\hline & & \multicolumn{6}{|c|}{ Mean Number of Days in Year } \\
\hline \multirow{4}{*}{$\begin{array}{l}\text { Maximum wind } \\
\text { speed } \geq 10 \mathrm{~m} \mathrm{~s}^{-1}\end{array}$} & Świnoujście & 24 & 41 & 47 & 22 & 28 & 32 \\
\hline & Kołobrzeg & 14 & 10 & 4 & 3 & 2 & 6 \\
\hline & Ustka & 34 & 24 & 15 & 34 & 95 & 40 \\
\hline & Hel & 64 & 85 & 39 & 18 & 11 & 43 \\
\hline \multirow{4}{*}{$\begin{array}{c}\text { Minimum air } \\
\text { temperature }>0{ }^{\circ} \mathrm{C}\end{array}$} & Świnoujście & 275 & 287 & 290 & 292 & 289 & 286 \\
\hline & Kołobrzeg & 268 & 285 & 287 & 291 & 286 & 283 \\
\hline & Ustka & 308 & 308 & 308 & 308 & 308 & 308 \\
\hline & Hel & 267 & 282 & 287 & 293 & 292 & 284 \\
\hline \multirow{4}{*}{$\begin{array}{l}\text { Mean sea level } \\
\quad<502 \mathrm{~cm}\end{array}$} & Świnoujście & 169 & 174 & 134 & 149 & 112 & 148 \\
\hline & Kołobrzeg & 159 & 177 & 126 & 139 & 110 & 142 \\
\hline & Ustka & 158 & 156 & 121 & 137 & 109 & 136 \\
\hline & Hel & 144 & 158 & 114 & 123 & 122 & 132 \\
\hline \multirow{4}{*}{$\begin{array}{c}\text { Precipitation } \\
<5 \mathrm{~mm} / 2 \text { days }\end{array}$} & Świnoujście & 286 & 293 & 289 & 286 & 285 & 288 \\
\hline & Kołobrzeg & 272 & 279 & 279 & 275 & 267 & 274 \\
\hline & Ustka & 271 & 272 & 273 & 278 & 278 & 275 \\
\hline & Hel & 291 & 293 & 286 & 290 & 282 & 288 \\
\hline \multirow{4}{*}{$\begin{array}{l}\text { Particularly favorable } \\
\text { days for aeolian } \\
\text { processes } \\
\text { intensification }\end{array}$} & Świnoujście & 4 & 6 & 5 & 2 & 2 & 4 \\
\hline & Kołobrzeg & 1 & 1 & 0 & 0 & 0 & 0 \\
\hline & Ustka & 3 & 1 & 0 & 3 & 9 & 3 \\
\hline & Hel & 6 & 11 & 1 & 1 & 0 & 4 \\
\hline
\end{tabular}

Analysis of the number of days per year with conditions conducive to intensification of aeolian processes revealed a statistically significant downward trend for Kołobrzeg and Hel $(\mathrm{r} \sim-0.6)$, and a statistically significant upward trend for Ustka $(\mathrm{r} \sim+0.5)$ (Figure 7). For Świnoujście, this trend was statistically insignificant.

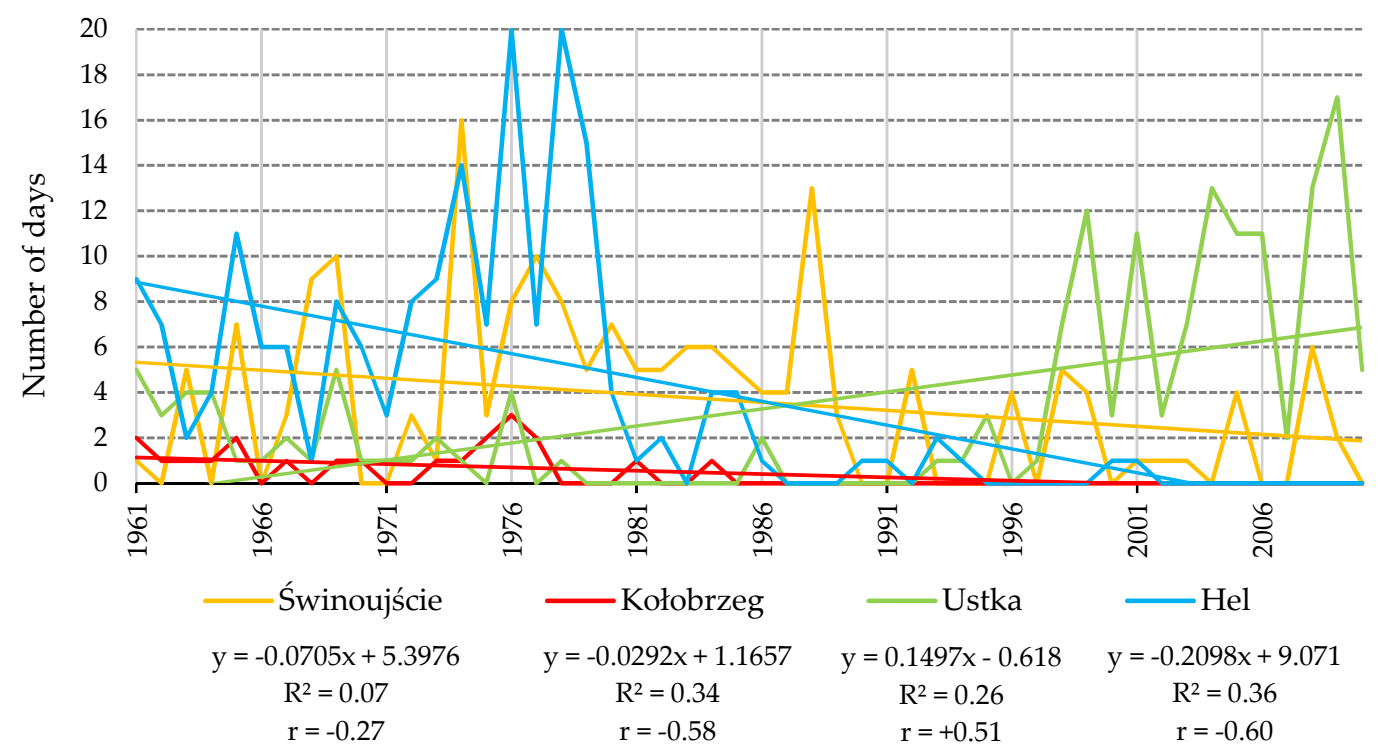

Figure 7. Annual trend of days with conditions particularly conducive to intensification of aeolian processes in the Polish Baltic coastal zone.

The occurrence of hydrometeorological conditions potentially favorable to initiation and particularly conducive to intensification of aeolian processes in the Polish Baltic coastal zone clearly depended on the seasons (Figure 8). During the cold half-year, especially from November to March, 
the number of days with conditions for the occurrence of aeolian processes was lower than from April to October. The cold half-year is the storm period, during which, despite higher wind speeds, storm surges are not conducive to aeolian processes, as they limit the availability of sandy beach sediments. Furthermore, during this period, there is a higher frequency of days with precipitation, as well as low temperatures causing ground frost. In the warm half-year, there are significantly fewer storm surges and days with precipitation, and no days with freezing temperatures. Conditions particularly favorable to the initiation and intensification of aeolian processes occurred especially in the spring, from April to June. At the beginning of spring, hydrometeorological conditions for the occurrence of aeolian processes were exceptionally favorable, as vegetation was not fully developed at the beginning of the season, and therefore did not limit the availability of sandy sediments for aeolian processes. Additionally, the inflow of dry masses of continental air from the Northeast were frequently recorded during this time.

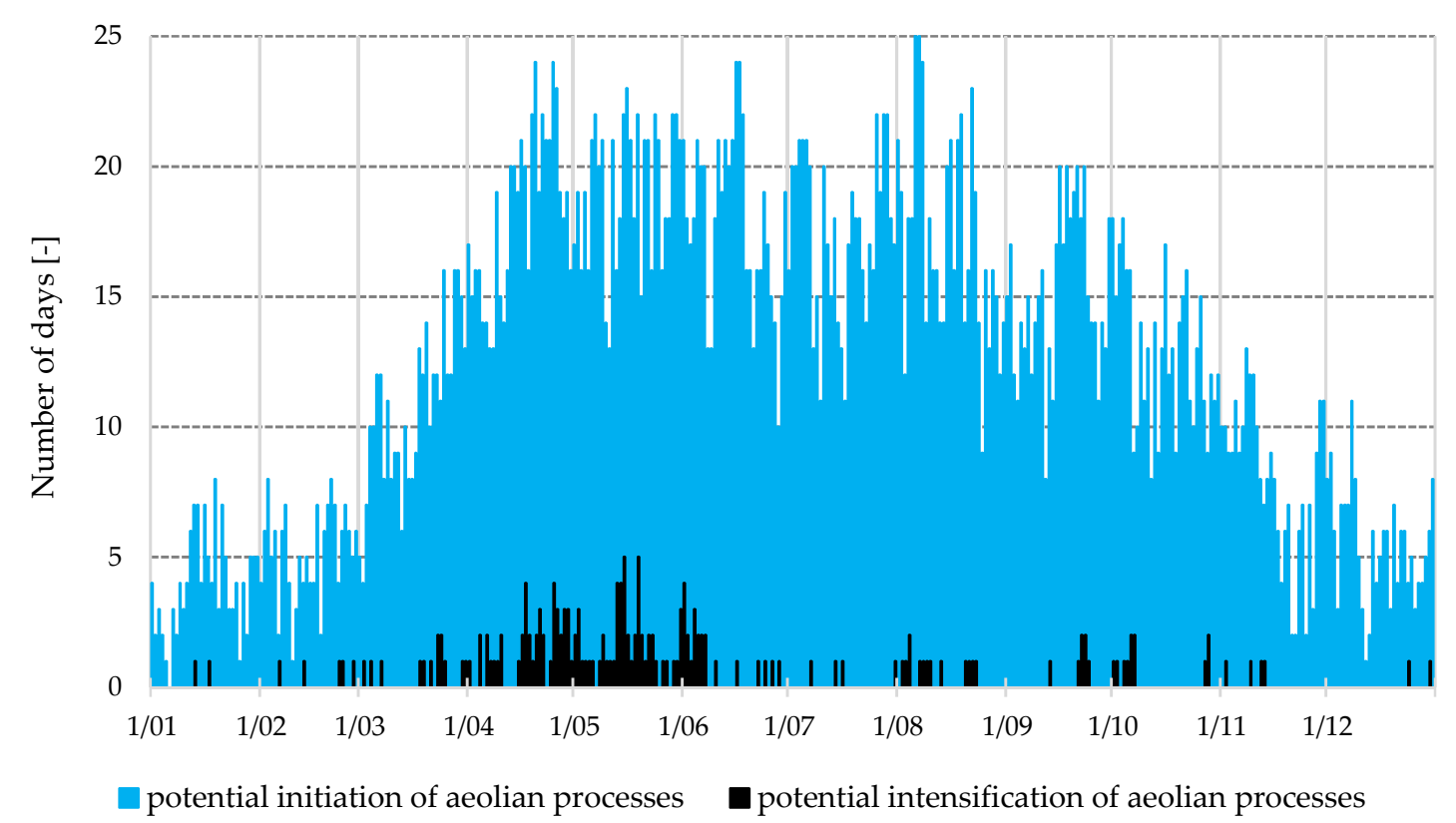

Figure 8. Seasonal dynamics of the number of days with conditions potentially favorable to initiation and particularly conducive to intensification of aeolian processes in the Polish Baltic coastal zone-a case study on Świnoujście 1961-2010.

For the Polish Baltic coastal zone, analysis of the general trend in occurrence of hydrometeorological conditions potentially favorable to initiation and particularly conducive to intensification of aeolian processes (based on the maximum number of days per year with conditions for aeolian processes recorded by all four measurement stations) revealed statistically significant patterns (Figure 9). For hydrometeorological conditions potentially favorable to initiation of aeolian processes, an upward trend was observed. However, for hydrometeorological conditions particularly conducive to initiation of aeolian processes, a downward trend was observed. The hydrometeorological conditions from 1961 to 2010 were thus characterized by a certain increase in the number of events (days) with conditions for the occurrence of aeolian processes, albeit of relatively low intensity. 


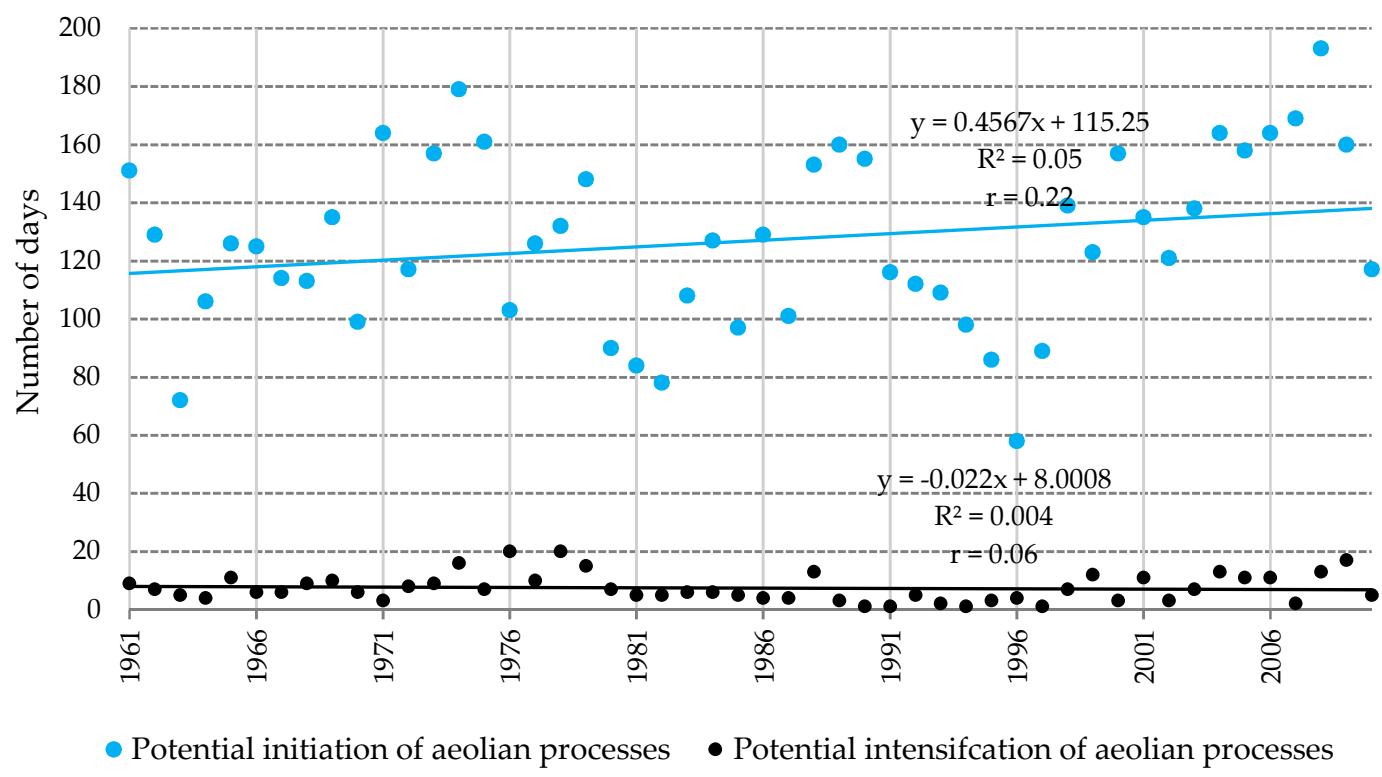

Figure 9. Trend in the number of days with hydrometeorological conditions potentially favorable to initiation and particularly conducive to intensification of aeolian processes in the Polish Baltic coastal zone.

\section{Discussion}

Research on the mechanism of aeolian processes in the coastal zone (especially quantitative values and the laws governing the movement of particles by wind) conducted in natural conditions [11,42,43], as field experiments $[5,10,15,34,44,45]$, and especially as laboratory experiments $[46,47]$ has often yielded divergent results. The number of variables determining the mechanism of aeolian processes in the coastal zone is much higher than in desert areas, especially in laboratory conditions (wind tunnels).

Field observations have shown that aeolian processes have positive and negative effects in geomorphological transformations of the coastal zone. The first group contains reconstruction of the beach after storms and during interstorm periods [9]. At this time, sand can be transported by winds from the beach to the dunes $[1,9,10,34,45,48]$. Ripple marks form on the surface of the beach, as well as aeolian shadows behind various obstacles, transverse sand patches, or even small barchans [10]. The second group contains lowering of the beach surface by seaward and alongcoast winds $[4,9,49]$. The visible effect of lowering of the beach is aeolian pavement and microshadows behind small obstacles [10].

During a storm build-up, the transverse profile of the beach (width and height) is of great importance; the beach can be flooded completely. During weakening of the storm, the aeolian processes act the most quickly on the upper beach fragment at the base of the dunes or cliff. During large storms, at sea level of $570 \mathrm{~cm}$, sea waves cause erosion of sand dunes [1,41]. Such a situation occurs in many places on the Polish coast, even on beaches with a width of up to $70 \mathrm{~m}$, which have low altitudes.

The threshold hydrometeorological conditions potentially favorable to initiation and particularly conducive to intensification of aeolian processes determined in the study are a kind of generalization. The threshold values were determined based on a review of literature concerning field research on the dune coastal zone $[5,9,10,38]$, and original research on the cliff coastal zone [2,3]. We can assume that the hydrometeorological criteria used in this study are very general, but appropriate for the South Baltic coastal zone.

Analysis of the variability of hydrometeorological conditions over time on the Polish coast revealed patterns similar to those found in other studies on the South Baltic coast [50-52]. Current trends and forecasts of climatic conditions in the South Baltic coastal zone indicate that for every 10-year interval, the average annual air temperature will increase by $1.9^{\circ} \mathrm{C}$, and the annual sum of precipitation will decrease by $4 \%$ (meaning around $30 \mathrm{~mm}$ ) [53]. The trend of increasing temperatures, 
especially during winter $\left(1.7-2.3^{\circ} \mathrm{C}\right)$, will limit the number of days on which freezing temperatures freeze the ground, and as a consequence, improvement of conditions unfavorable to the functioning of aeolian processes. Furthermore, the drop in precipitation will most likely reduce the number of days with precipitation, and thus increase the occurrence of conditions favorable to aeolian processes. Additionally, the observed increase in sea level by $3-4 \mathrm{~cm}$ every 10 years [41] may reduce the width of beaches and the availability of sandy sediments for aeolian processes. The increase in the level of the South Baltic Sea is insignificantly higher than the forecasted rise in global sea level, which is estimated at $1-2 \mathrm{~mm} \cdot \mathrm{a}^{-1}$ [54].

The high number of days with conditions potentially favorable to aeolian processes from 1971 to 1980 was accompanied by high annual intensity of potential aeolian transport. In this decade, the value of aeolian transport in Świnoujście was estimated at around $1075 \mathrm{t} \cdot \mathrm{m}^{-1}$-from $\sim 80 \mathrm{t} \cdot \mathrm{m}^{-1}$ in 1972 to $\sim 150 \mathrm{t} \cdot \mathrm{m}^{-1}$ in 1977 [4]. During the same period in Kołobrzeg, there were significantly fewer hydrometeorological events favorable to initiation of aeolian processes. The average annual value of aeolian transport was around $395 \mathrm{t} \cdot \mathrm{m}^{-1}$-from $\sim 30 \mathrm{t} \cdot \mathrm{m}^{-1}$ in 1980 to $\sim 60 \mathrm{t} \cdot \mathrm{m}^{-1}$ in 1975 [4]. According to Reference [4], $80 \%$ of the total aeolian transport takes place during $8 \%$ of the year (for about 1 month). The period of potential increase in aeolian transport (1 month) therefore constituted $30 \%$ to $50 \%$ of the average annual number of days with conditions favorable to aeolian processes (92 days in Świnoujście and 64 days in Kołobrzeg).

\section{Conclusions}

The relationship between hydrometeorological conditions and aeolian processes in the coastal zone is not linear. Extremely high wind speed does not always generate extreme aeolian erosion, transport, and accumulation on beaches and the slopes of dunes and cliffs, especially when strong winds are accompanied by storm surges and significant precipitation. The geomorphological effects of wind in the coastal zone are determined by many other factors that disturb the relationship between hydrometeorological conditions and aeolian processes. Among the most important of these factors are: Morpholytic conditions on beaches and the slopes of dunes and cliffs; surface exposure to wind; land cover from vegetation in different seasons; the dynamics and frequency of previous extreme hydrometeorological events; and human activity (e.g., hydraulic engineering).

Temporal and spatial analysis of hydrometeorological conditions determining initiation and intensification of aeolian processes in the South Baltic coastal zone in Poland yielded the following conclusions:

- The hydrometeorological and morpholithodynamic conditions of the coastal zone are conducive to aeolian processes. The average annual number of days with conditions favorable to initiation of aeolian processes is particularly high in terms of sea level (360 days) and air temperature (319 days). This number is slightly lower for wind speed (296 days), and lowest for precipitation (128 days). All of these factors must occur simultaneously for the initiation of aeolian processes. For this reason, the average annual number of potentially favorable events was 85 . The number of days with conditions particularly conducive to intensification of aeolian processes was significantly lower (only three). While the average annual number of days with conducive conditions in terms of air temperature and precipitation was high (290 and 281 days), this number was significantly lower for sea level (140 days), and negligible for wind speed (only 10 days). Therefore, the average annual number of days with conditions potentially favorable to initiation of aeolian processes is nearly 30 times greater than the number of days with conditions particularly conducive to their intensification.

- The Pomeranian Bay (Świnoujście) and Gdańsk Bay (Hel) are particularly predisposed to the occurrence of hydrometeorological conditions potentially favorable to aeolian processes. In these areas, aeolian processes can occur for over 3 months per year on average. In the open coastal zone, aeolian processes can occur for around 2 months per year on average, e.g., in Kołobrzeg. 
- The upwards trend of conditions particularly favorable to the intensification of aeolian processes for Ustka is probably related to the coastline's exposure to seaward winds. An additional effect may be the increase in share of winds associated with storms.

- Clustering of high frequencies of potential aeolian processes occurred in the 1970s. The lowest frequency of hydrometeorological conditions for the occurrence of aeolian processes was recorded in the first decade of the 21st century. Aeolian processes may occur on as few as 32 days per year (Kołobrzeg, 2010), and as many as 143 days per year (Świnoujście and Hel, 1989). In seasonal terms, the hydrometeorological conditions most conducive to initiation and intensification of aeolian processes occurred in the spring, especially from April to June.

- Conditions conducive to intensification of aeolian processes indicate that there is positive and negative wind activity within the coastal zone. Seaward wind directions cause formation of forms on the beach and build up foredunes. In addition, they cause flooding of promenades, pavements and streets in seaside resorts. Inland wind directions cause dissipation of dunes and clear off sandy material to the sea. Seaward and alongshore directions contribute to lowering of the beach area and transporting sand to other sections of the beach.

Regional climate models (RCM) predict climate change in the upcoming few decades involving the increase of temperature and precipitation [55]. The efficiency of daily rainfall is also to increase [56], and their frequency will be lower [57]. More frequent and longer periods of heat waves are predicted [16] as well as the possibility of long periods of drought [58], which will be conducive to the functioning of aeolian processes. The number of days potentially beneficial and particularly favorable to aeolian processes is likely to increase. An increase in their intensity is also expected.

Considering the current trend of rising sea levels, climatic changes, and the increasing frequency of extreme hydrometeorological events in the South Baltic coastal zone, it is not possible to reliably forecast the frequency of aeolian processes. However, the results of this study may be useful for determining how the coast functions, especially its beaches, coastal dunes, and moraine cliffs, whose low resistance to aeolian erosion is characteristic for the Baltic coast from Germany to Estonia.

Author Contributions: Conceptualization, M.H. and J.T.; Data curation, M.H. and J.T.; Formal analysis, M.H. and J.T.; Funding acquisition, M.H. and J.T.; Investigation, M.H., J.T. and M.R.; Methodology, M.H.; Project administration, M.H. and J.T.; Resources, M.H. and J.T.; Validation, J.T.; Visualization, M.H., J.T. and M.R.; Writing—original draft, M.H. and J.T.; Writing—review and editing, M.H and M.R.

Funding: The APC was funded by the Polish Ministry of Science (Project Supporting Maintenance of Research Potential of the Department of Physical Edu., Health and Tourism at Kazimierz Wielki University no. BS/2016/N1).

Acknowledgments: Hydrometeorological data were obtained from the Institute of Meteorology and Water Management, National Research Institute in Warsaw. We would like to thank the four reviewers for very helpful comments that improved our paper substantially.

Conflicts of Interest: The authors declare no conflict of interest.

\section{References}

1. Łabuz, T.A. Polish coastal dunes-Affecting factors and morphology. Landf. Anal. 2013, 22, 33-59. [CrossRef]

2. Hojan, M. Aeolian processes on the cliffs of Wolin Island. In Quaestiones Geographicae; Adam Mickiewicz University Press: Poznań, Poland, 2009; Volume 28, pp. 39-46. ISBN 978-83-232-2133-3.

3. Hojan, M.; Więcław, M. Influence of meteorological conditions on aeolian processes along the Polish cliff coast. Baltica 2014, 27, 61-72. [CrossRef]

4. Borówka, R.K. Multi-year trends of change in the intensity of potential aeolian transport on the West Pomeranian Coast of the Baltic in context of the morphology and present-day development of coastal dunes. In Quaternary Studies in Poland SI; Polish Scientific Publishers PWN: Warszawa, Poland, 1999; pp. 67-75.

5. Hildebrandt-Radke, I. The effect of meteorological factors on aeolian transport on the beach of the Gardno-Łeba Barrier. In Quaternary Studies in Poland SI; Polish Scientific Publishers PWN: Warszawa, Poland, 1999; pp. 109-114. 
6. Hildebrandt-Radke, I. Rola szerokości plaży w nasyceniu strumienia wiatrowo-piaszczystego na plaży Mierzei Gardnieńsko-Łebskiej. Badania Fizjograficzne nad Polska Zachodnia 2002, 53, 43-56.

7. Borówka, R.K. Present day dune processes and dune morphology on the Łeba Barrier, polish coast of the Baltic. Geografiska Annaler 1980, 62A, 75-82. [CrossRef]

8. Borówka, M.; Rotnicki, K. Balance of the aeolian sand transport on the beach and the problem of sand nourishment of the active dune field on the Łeba Barrier. J. Coast. Res. 1995, 22, 257-265.

9. Borówka, M.; Rotnicki, K. Main directions of aeolian sand transport and its budget on barier sandy beach (Łeba Barrier case study). In Ewolucja Geosystemów Nadmorskich Południowego; Bałtyku, R.K., Borówka, Z., Młynarczyk, A., Eds.; Bogucki Wyd. Nauk.: Szczecin, Poland, 1999; pp. 17-24. ISBN 83-88163-02-7.

10. Rotnicka, J. Aeolian Sand Transport on a Tideless Beach: Rate, Controlling Factors and Influence on Foredune Formation (Łeba Barrier Case, Poland); Bogucki Wyd. Nauk.: Poznań, Poland, 2013; ISBN 978-83-63400-71-2.

11. Rotnicka, J. Aeolian vertical mass flux profiles above dry and moist sandy beach surfaces. Geomorphology 2013, 187, 27-37. [CrossRef]

12. Zawadzka-Kahlau, E. Morphodynamics of Southern Baltic Dune Coasts; Wydawnictwo Uniwersytetu Gdańskiego: Gdańsk, Poland, 2012; ISBN 978-83-7865-016-4.

13. Žilinskas, G.; Jarmalavièius, D.; Pupienis, D. The influence of natural and anthropogenic factors on grain size distribution along the south eastern Baltic spits. Geol. Q. 2018, 62, 375-384.

14. Bauer, B.O.; Davidson-Arnott, R.G.D.; Hesp, P.A.; Namikas, S.L.; Ollerhead, J.; Walker, I.J. Aeolian sediment transport on a beach: Surface moisture, wind fetch, and mean transport. Geomorphology 2009, 105, 106-116. [CrossRef]

15. Rotnicka, J. Impact of beach surface type on the rate of sand transport by wind. In Proceedings of the 11th International Coastal Symposium, Szczecin, Poland, 9-13 May 2011; pp. 2058-2062.

16. Nikulin, G.; Kjellström, E.; Hansson, U.; Jones, C.; Strandberg, G.; Ullerstig, A. Evaluation and future projections of temperature, precipitation and wind extremes over Europe in an ensemble of regional climate simulations. Tellus 2011, 63A, 41-55. [CrossRef]

17. Bierstedt, S.E.; Hünicke, B.; Zorita, E. Variability of wind direction statistics of mean and extreme wind events over the Baltic Sea region. Tellus 2015, 67, 29073. [CrossRef]

18. Bierstedt, S.E.; Hünicke, B.; Zorita, E.; Ludwig, J. A wind proxy based on migrating dunes at the Baltic coast: Statistical analysis of the link between wind conditions and sand movement. Earth Syst. Dyn. 2017, 8, 639-652. [CrossRef]

19. Rutgersson, A.; Jaagus, J.; Schenk, F.; Stendel, M.; Bärring, L.; Briede, A.; Claremar, B.; Hanssen-Bauer, I.; Holopainen, J.; Moberg, A.; et al. Recent Change-Atmosphere. In Second Assessment of Climate Change for the Baltic Sea Basin; Springer International Publishing: Berlin, Germany, 2015; pp. 69-97.

20. Clemmensen, L.B.; Hansen, K.W.T.; Kroon, A. Storminess variation at Skagen, northern Denmark since ad 1860: Relations to climate change and implications for coastal dunes. Aeolian Res. 2014, 15, 101-112. [CrossRef]

21. Hünicke, B.; Zorita, E. Influence of temperature and precipitation on decadal Baltic Sea level variations in the 20th century. Tellus 2006, 58A, 141-153. [CrossRef]

22. Jaagus, J.; Kull, A. Changes in surface wind directions in Estonia during 1966-2008 and their relationships with large-scale atmospheric circulation. Estonian J. Earth Sci. 2011, 60, 220-231. [CrossRef]

23. Reimann, T.; Tsukamoto, S.; Harff, J.; Osadczuk, K.; Frechen, M. Reconstruction of holocene coastal foredune progradation using luminescence dating-An example from the Swina Barrier (Southern Baltic sea, NW Poland). Geomorphology 2011, 132, 1-16. [CrossRef]

24. Subotowicz, W. Transformation of the cliff coast in Poland. J. Coast. Res. 1995, 22, 57-62.

25. Molodkov, A.; Bitinas, A. Sedimentary record and luminescence chronology of the Lateglacial and Holocene aeolian sediments in Lithuania. Boreas 2006, 35, 244-254. [CrossRef]

26. Kovaleva, A.; Chubarenko, B.; Pupienis, D. Grain size variability as an indicator of sediment transport alongshore the Curonian Spit (south-eastern Baltic Sea). Baltica 2016, 29, 145-155. [CrossRef]

27. Rotnicki, K.; Borzyszkowska, W. Accelerated sea level rise and its components at the Polish Baltic Coast in the years 1951-1990. In Ewolucja Geosystemów Nadmorskich Południowego Bałtyku; Borówka, R.K., Młynarczyk, Z., Wojciechowski, A., Eds.; Bogucki Wydawnictwo Naukowe: Poznań, Poland; Szczecin, Poland, 1999; pp. 141-160. ISBN 83-88163-02-7. 
28. Rosentau, A.; Bennike, O.; Uścinowicz, S.; Miotk-Szpiganowicz, G. The Baltic Sea Basin. In Submerged Landscapes of the European Continental Shelf: Quaternary Paleoenvironments, 1st ed.; Flemming, N.C., Harff, J., Moura, D., Burgess, A., Bailey, G.N., Eds.; John Wiley \& Sons Ltd.: Hoboken, NJ, USA, 2017; pp. 103-133. [CrossRef]

29. Wolski, T. Spatial and Temporal Characteristics of the Extreme Sea Levels of the Baltic Sea; Wydawnictwo Naukowe Uniwersytetu Szczecińskiego: Szczecin, Poland, 2017; ISBN 978-83-7972-091-0.

30. Sztobryn, M.; Stigge, H.J. Storm Surges on the Southern Baltic Sea; IMGW Press: Warszawa, Poland, 2005; ISBN 83-88897-61-6.

31. Wiśniewski, B.; Wolski, T. Occurrence probability of maximum sea levels in Polish ports of Baltic Sea coast. Pol. Mar. Res. 2009, 3, 62-69. [CrossRef]

32. Łabuz, T.A.; Grunewald, R.; Bobykina, V.; Chubarenko, B.; Česnulevičius, A.; Bautrenas, A.; Morkunaite, R.; Tõnisson, H. Coastal dunes of the Baltic Sea shores: A review. Quaest. Geogr. 2018, 37, 47-71. [CrossRef]

33. Koraim, A.S.; Heikal, E.M.; AboZaid, A. Different methods used for protecting coast from sea level rise caused by climate change. Curr. Dev. Oceanogr. 2011, 3, 33-66.

34. Rotnicka, J. Factors controlling the development of foredunes along the Łeba Barrier on the south Baltic coast of Poland. In Proceedings of the 11th International Coastal Symposium, Szczecin, Poland, 9-13 May 2011.

35. Zhang, W.; Schneider, R.; Kolb, J.; Teichmann, T.; Dudzinska-Nowak, J.; Harff, J.; Hanebuth, T.J.J. Land-sea interaction and morphogenesis of coastal foredunes-A modeling case study from the Southern Baltic Sea coast. Coast. Eng. 2015, 99, 148-166. [CrossRef]

36. Kostrzewski, A.; Zwoliński, Z.; Winowski, M.; Tylkowski, J.; Samołyk, M. Cliff top recession rate and cliff hazards for the sea coast of Wolin Island (Southern Baltic). Baltica 2015, 28, 109-120. [CrossRef]

37. Tylkowski, J. Hydro-meteorological conditions underpinning cliff-coast erosion on Wolin Island, Poland. Przeglad Geograficzny 2018, 90, 111-135. [CrossRef]

38. Ludwig, J.; Lindhorst, S.; Betzler, C.; Bierstedt, S.E.; Borówka, R.K. Sedimentary rhythms in coastal dunes as a record of intra-annual changes in wind climate (Łeba, Poland). Aeolian Res. 2017, 27, 67-77. [CrossRef]

39. Riksen, M.J.P.; Goossens, D. The role of wind and splash erosion in inland drift-sand areas in the Netherlands. Geomorphology 2007, 88, 179-192. [CrossRef]

40. Subotowicz, W. Litodynamika Brzegów Klifowych Wybrzeża Polski; Gdańskie Towarzystwo Naukowe, Ossolineum: Wrocław, Poland, 1982; ISBN 83-04-01301-0.

41. Tylkowski, J. The temporal and spatial variability of coastal dune erosion in the Polish Baltic coastal zone. Baltica 2017, 30, 97-106. [CrossRef]

42. Kadib, A.A. Mechanism of sand movement on coastal dunes. Proceedings of the American Society of Civil Engineers. Waterw. Div. 1966, 2, 27-44.

43. Svasek, J.; Terwindt, J. Measurements of sand transport by wind on a natural beach. Sedimentology 1974, 21, 311-322. [CrossRef]

44. Horikawa, K.; Hotta, S.; Kubota, S.; Katori, S. On the sand transport rat by wind on beach. Coast. Eng. Jpn. 1983, 26, 101-120. [CrossRef]

45. Psuty, N.P. Sediment budget and dune/beach interaction. J. Coast. Res. SI 1988, 3, 1-4.

46. McEwan, I.K.; Wilets, B.B. On the prediction of bed-load sand transport rate in air. Sedimentology 1994, 41, 1241-1251. [CrossRef]

47. Sherman, D.J.; Li, B.; Ellis, J.T.; Farrell, E.J.; Maia, L.P.; Granja, H. Recalibrating Aeolian sand transport models. Earth Surf. Processes Landf. 2013, 38, 169-178. [CrossRef]

48. Hesp, P.A. Foredune formation in Southeast Australia. In Coastal Geomorphology in Australia; Thom, B.G., Ed.; Academic Press: Sydney, Australia, 1984; pp. 69-97.

49. Łabuz, T.A. Morphodynamics and rate of Cliff erosion in Trzęsacz (1997-2017). Landf. Anal. 2017, 34, 29-50. [CrossRef]

50. Swiątek, M. Precipitation changes on the Polish coast of the Baltic Sea (1954-2003) due to changes in intensity of westerlies over Europe. Clim. Res. 2011, 48, 23-29. [CrossRef]

51. Tylkowski, J. Temporal and spatial variability of air temperature and precipitation at the Polish coastal zone of the Southern Baltic Sea. Baltica 2013, 26, 83-94. [CrossRef]

52. Wiśniewski, B.; Wolski, T.; Musielak, S. A long-term trend and temporal fluctuations of the sea level at the Polish Baltic coast. Oceanol. Hydrobiol. Stud. 2011, 40, 96-107. [CrossRef] 
53. Mietus, M. Variability of Air Temperature and Precipitation in the Polish Baltic Coast and its Expected Course until 2030; Materiały Badawcze: Meteorologia, Poland, 1996.

54. Russell, G.L.; Gornitz, V.; Miller, J.R. Regional sea level changes projected by the NASA/GISS atmosphere-ocean model. Clim. Dyn. 2000, 16, 789-797. [CrossRef]

55. Collins, M.; Knutti, R.; Arblaster, J.; Dufresne, J.L.; Fichefet, T.; Friedlingstein, P.; Wehner, M. Long-term climate change: Projections, commitments and irreversibility. In Climate Change the Physical Science Basis (1029-1136), Contribution of Working Group I to the Fifth Assessment Report of the Intergovernmental Panel on Climate Change; Cambridge University Press: Cambridge, UK, 2013.

56. Christensen, O.B.; Kjellström, E.; Zorita, E. Projected Change-Atmosphere. In The BACC II Author Team Second Assessment of Climate Change for the Baltic Sea Basin; Regional Climate Studies; Springer: Cham, Switzerland, 2015; ISBN 978-3-319-16006-1.

57. Lehtonen, I.; Ruosteenoja, K.; Jylhä, K. Projected changes in European extreme precipitation indices on the basis of global and regional climate model ensembles. Int. J. Climatol. 2014, 34, 1208-1222. [CrossRef]

58. Orlowsky, B.; Seneviratne, S.I. Global changes in extreme events: Regional and seasonal dimension. Clim. Chang. 2012, 110, 669-696. [CrossRef]

(C) 2018 by the authors. Licensee MDPI, Basel, Switzerland. This article is an open access article distributed under the terms and conditions of the Creative Commons Attribution (CC BY) license (http:/ / creativecommons.org/licenses/by/4.0/). 